\title{
AN AUTHORITY IN ACTION-AN ACCOUNT OF THE PORT OF NEW YORK AUTHORITY AND ITS RECENT ACTIVITIES*
}

\author{
SIDNEY GoLDSTEIN†
}

\section{INTRODUCTION}

The following is a discussion of the New York Port Authority's most recent contributions in coping with the complex terminal and transportation problems which beset the huge metropolitan area which it serves. It covers, first, the Port Authority's creation; second, its organizational and financial structure; third, the means by which it is subject to popular control; and finally, recent Port Authority endeavors which dramatize the agency's dynamic character.

Before commencing this discussion, I should like to point out that the Port Authority is currently operating twenty-two terminal and transportation facilities in the metropolitan area of New York and northern New Jersey, an area composed of over $13,000,000$ people residing in more than 360 separate and distinct communities, embracing 220 municipalities. Port Authority facilities represent a net capital investment of over one billion dollars. They consist of four bridges and two tunnels between the States of New York and New Jersey, four airports, and two heliports, six marine terminals, three inland freight terminals, a grain terminal and a bus terminal. In addition, the Port Authority maintains nine regional trade development offices in the United States and overseas, appears continuously before Congress and federal agencies on matters of concern to the commerce of the Port and makes periodic studies of ways to improve that commerce, including the feasibility of providing additional terminal and transportation facilities. ${ }^{1}$

\section{The Creation of the Port Authority}

An accident of history divided the geographically unified Port of New York area between the Colonies of New York and New Jersey. Throughout the nineteenth century this division led to many interstate quarrels, the most famous of which concerned the Hudson River steamboat monopoly that New York had granted to Robert Livingston and Robert Fulton-a dispute which culminated in Chief Justice

* This paper was presented to the Municipal Law Section of the American Bar Association at its meeting in Miami Beach, Fla., Aug. 25, 1959. It does not include any reference to the current controversy over the kind and degree of federal interest in the Port of New York Authority. See United States v. Tobin, 195 F. Supp. 588 (D.D.C. I96I). Mr. Goldstein believes that since this case is presently before the United States Court of Appeals for the District of Columbia, comment by him on the matter in controversy would not be appropriate.

TLL.B. I930, St. John's College, Brooklyn, N.Y. General Counsel, The Port of New York Authority, Member of New York, Federal, and American Bar Associations.

${ }^{1}$ This paragraph includes the development of Port Authority facilities subsequent to the preparation of this paper in 1959 . 
Marshall's famous decision in Gibbons v. Ogden ${ }^{2}$ upholding the federal government's commerce power as against conflicting state action.

In describing the reasons for the Port Authority's creation, two factors deserve special mention. The first was the insistence by New Jersey interests that railroad freight rates to their portion of the Port District should be adjusted to take into account New Jersey's geographical position on the landward side of the harbor. When the issue reached the Interstate Commerce Commission in 1917, the Commission, in denying that existing rates were prejudicial to New Jersey, said: ${ }^{3}$

... historically, geographically, and commercially New York and the industrial district in the northern part of the State of New Jersey.constitute a single community

and

... cooperation and initiative must eventually bring about the improvements and benefits which the complainants hope to attain through a change in the rate adjustment.

The second reason leading to the Port Authority's creation was the inability of the Port's archaic terminal and transportation facilities to handle efficiently the everincreasing amount of goods that sought to use the harbor or were needed to support the region's growing population, a fact that became painfully apparent from the bottlenecks that developed during World War I.

To solve these and other problems, the New York Legislature in I9I7 created a study commission to act jointly with a similar agency created by New Jersey. The separate commissions organized themselves as a single body known as The New York, New Jersey Port and Harbor Development Commission.

After more than three years of study the Commission compiled an extensive report urging the creation of a permanent interstate agency as the fundamental condition to the carrying out of a unified program of port improvement. The report advocated use of the "Compact Clause" of the Federal Constitution, authorizing the States to enter into compacts with one another, to establish a regional port authority. Until this time the "Compact Clause" had lain dormant-having only been used in the adjustment of state boundary disputes.

The Commission's recommendation bore fruit when in rg2r both States entered into an Interstate Compact ${ }^{5}$ creating the Port Authority, a new and different type of public agency, for the express purpose of developing the Port District on a joint and cooperative basis.

\section{The Port Authority's Organizational and Financial Structure}

Though the Port Authority is defined as "the municipal corporate instrumentality of the two States," the methods it employs in fulfilling its governmental responsibilities are those of a private business corporation. The Port Authority consists of a

${ }^{2} 22$ U.S. (9 Wheat.) I (1824).

${ }^{3}$ The New York Harbor Case, 47 I.C.C. 643,739 (1917).

${ }^{2}$ U.S. ConsT. art. I, $\$$ Io, cl. 3 .

N.Y. Unconsol. LAws tit. $x 7$ (McKinney 1953); N.J. Stat. ANN. tit. 32 (1940).

- N.Y. Unconsol. Laws § 645I (McKinney I953); N.J. Stat. ANn. § 32:1-25 (1940). 
Board of twelve Commissioners-six appointed by each Governor with the advice and consent of the respective State Senates for overlapping terms. The Commissioners are subject to removal for cause and serve without compensation, the absence of which may account for the fact that Commissioners have invariably been outstanding business leaders, professional men, or educators. Time and time again, the Governors have re-appointed Commissioners without regard to partisan considerations. This has enabled the Port Authority to achieve a continuity in management essential to a sound program of port planning. It has also enabled the Port Authority to adopt the most advanced techniques of modern corporate personnel management to develop a career staff of able and conscientious employees.

Though the Port Authority is given the power to borrow money and secure the same by bonds, ${ }^{7}$ it is expressly denied the power to levy taxes ${ }^{8}$ or to pledge the States' credit in support of its securities. ${ }^{9}$ Thus, Port Authority facilities must be self-supporting, and to the Port Authority, as to a private business corporation, can be applied the acid test of the balance sheet.

The Port Authority does not undertake projects which private enterprise can handle. However, it insists on making certain that each group of facilities should ultimately be self-sustaining. This means that the Port Authority operates within a narrow margin of financial practicability and most of its projects have involved heavy developmental losses which private enterprise was unwilling to assume. As we have seen, Port Authority facilities now represent a net capital investment of over $\$ 850,000,000$, financed by bonds backed solely by the revenues and reserves of Port Authority projects, without charge to the general taxpayer.

\section{Popular Control Over the Port Authority}

Although the Port Authority enjoys administrative flexibility not possessed by departments of State government, it operates nonetheless within the framework of traditional democratic concepts.

a. Legislative Authorization and Continuing Review. The Compact specifies that, ${ }^{10}$

The port authority shall have such additional powers and duties as may hereafter be delegated to .... it from time to time by the action of the legislature of either state concurred in by the legislature of the other.

In point of fact, the Port Authority has procured additional bi-state legislation in connection with practically every major project it has undertaken. The almost annual passage of legislation relating to the Port Authority has given both Legislatures constant occasion to review and supervise Port Authority performance. The

${ }^{7}$ N.Y. UNCoNsox. LAwS $\$ 6407$ (McKinney 1953); N.J. Stat. ANN. $\S 32: 1-7$ (1940).

${ }^{8}$ N.Y. Unconsol. Laws $\$ 6459$ (McKinney 1953); N.J. Stat. AnN. \$ 32:T-33 (1940).

- N.Y. Unconsol. LAwS $\$ 6408$ (McKinney I953); N.J. Stat. ANn. $\$ 32: 1-8$ (1940); consented to by Congress, 42 Stat. I74 (rg2r). See also, N.Y. Unconsol. Laws \$ 645I (McKinney I953); N.J. STAT. ANw. $532: 1-25$ (1940).

${ }_{20}$ N.Y. Unconsol. LAWs $\$ 6408$ (MeKinney I953); N.J. Stat. ANN. $\$ 32:$ I-8 (1940).. 
Compact assured that this continuing review would be exercised intelligently by requiring the Port Authority to make an annual report to the Legislatures "setting forth in detail the operations and transactions conducted by it. ..."11

b. Executive Review. The most dramatic example of continuing democratic control over Port Authority activity is that represented by the gubernatorial veto. The Port Authority must submit the minutes of its Board of Commissioners to both Governors and each shall, within ten days ${ }^{12}$

... cause the same to be returned to the Port Authority either with or without his veto on any action therein recited as having been taken by any Commissioner appointed from [his] state.

The mere possession of this power by the Governors results in continuing collaboration between them and the Commissioners. Its infrequent exercise is proof that Port Authority policies are consistent with those of the Governors.

c. Local Government Participation. Though the Port Authority is an agency of the States and thus by virtue of well-established law is not subject to municipal regulation, ${ }^{13}$ the States nevertheless, in certain specific instances where they believed the public interest would best be served, have required municipal consent as a prerequisite to Port Authority action. Thus, in the normal situation the Port Authority cannot condemn municipal property ${ }^{14}$ and hence the execution of Port Authority plans are dependent upon the Port Authority's ability to reach voluntary agreements with municipalities.

Moreover, the coordinated development and operation of the major air terminals in the Port District could only have been achieved by Port Authority-municipal cooperation authorized by specific legislation, ${ }^{15}$ pursuant to which the Port Authority has entered into long term leases with the Cities of New York and Newark providing for Port Authority operation of New York International, La Guardia and Newark Airports.

\section{Recent Port Authority Activities}

I should now like to bring you up to date on recent Port Authority undertakings which I believe underscore the fact that terminal and transportation questions are

11 Ibid.

${ }^{19}$ N.Y. Laws r927, ch. 700, § 2, as amended, id. 1956, ch. 215; N.J. STAT. ANN. $\$ 32: 2-7$ (1940).

${ }^{18}$ E.g., Port Authority v. Weehawken, 27 N.J. Super. 328 (Ch. Div. 1953), 99 A.2d 377 (1953), rev'd on other grounds, I4 N.J. 570, I03 A.2d 603 (1954). This case was later cited with approval in Bloomfield v. Highway Authority, I8 N.J. 237, II3 A.2d 658 (1955).

14 N.Y. Unconsol. LAws $\$ 6407$ (McKinney I953); N.J. STAT. ANN. \$32:I-7 (1940); consented to by Congress, 42 Stat. I74 (I92I). The sole exception is that in New Jersey the Port Authority may condemn municipal property necessary for George Washington Bridge purposes without municipal consent, although the consent of another state agency-the State House Commission-must be obtained. N.J. STAT. ANN. $\$ 32: \mathrm{r}-33 . \mathrm{I}$ ( $\mathrm{x} 960$ Supp.). At the present time, the Port Authority has reached an agreement with the Borough of Fort Lee relating to the acquisition of property owned by the Borough necessary for the second deck of the George Washington Bridge so as to avoid the necessity of going through the statutorily permissible condemnation procedure.

${ }^{18}$ N.Y. UNconsol. LAws $\$ \$ 6601-66$ I7 (McKinney I953); N.J. StAT. ANN. $\$ \$ 32: 1-35.1$ to 32:1-35.17 (I960 Supp.). 
never finally solved in a developing, expanding economy such as ours, but are continously requiring new studies, new plans and new projects, and thus present evernew challenges to the Port Authority.

a. Conquering the Port District's Water Barriers. Three years ago the Port Authority was operating two twin-tube tunnels and one bridge across the Hudson River, as well as three bridges joining New Jersey to Staten Island in New York.

Since that time the Port Authority has placed in operation a third two-lane tube to the Lincoln Tunnel at a cost of $\$ 95,000,000$ and in 1958 commenced construction of a second deck to the George Washington Bridge, including a bus passenger facility which is to be part of the expanded bridge. It is estimated that the cost of the total George Washington Bridge improvement, which is scheduled for completion in xg62, will exceed \$180 million.

You will recall that the second deck's construction was included in the recommendations contained in the Joint Study of Arterial Facilities conducted by the bi-state Port Authority and the single-state Triborough Bridge and Tunnel Authority, a New York City agency. This study recommended a vast construction program which included, in addition to the expanded George Washington Bridge, a new bridge across the Narrows of New York Harbor, linking Staten Island to Brooklyn. The program's purpose was to provide a system of vehicular bridges and highways which would make it possible for traffic not seeking to enter Manhattan to bypass that already congested island.

Before construction of the Narrows Bridge could be undertaken, many hurdles had to be surmounted. These included protracted negotiations with the Department of the Army for needed acquisition of certain federal fort properties and the execution of a definitive agreement between the two Authorities obligating the Port Authority to finance bridge construction and Triborough Bridge and Tunnel Authority to construct and operate the bridge as the Port Authority's lessee.

The ground-breaking ceremonies signaling the start of bridge construction were held in the summer of I959. The bridge, which is scheduled for completion in 1965, should present a majestic sight as it reaches across the Narrows with the longest suspension span of any bridge in the world. It will provide the first direct connection between Staten Island and the other four New York City boroughs. ${ }^{16}$

b. Marine Terminal Developments. Substantial progress has also been made in the Port Authority's program of marine terminal development. The Port Authority has recently acquired and put into operation on the Brooklyn waterfront a new marine terminal-the Erie Basin-Port Authority Piers. This, together with the Port Authority's contemplated $\$ 85,000,000$ development of the previously acquired Brooklyn-Port Authority Piers, will provide extensive modern marine terminal facilities to serve that portion of the Port's commerce which uses the New York waterfront.

\footnotetext{
${ }^{10}$ Financing of this facility has since been assumed by the Triborough Bridge and Tunnel Authority, and the bridge will be operated by that agency alone.
} 
The New Jersey waterfront has also been the scene of active Port Authority undertakings. Important improvements have recently been made at both Port Newark and the Hoboken-Port Authority Piers. In addition, as of April r958, the Port has commenced the development of a huge new $\$ 150,000,000$ marine terminal on Newark Bay in Elizabeth, New Jersey. This facility is scheduled to be in operation by 196I and is to be known as the Elizabeth-Port Authority Piers.

Furthermore, within the past two years, the Port Authority has acquired floating grain elevators for use in connection with its Grain Terminal located on the Brooklyn waterfront. These elevators are the only ones presently in operation in New York Harbor; they serve the entire port by performing the essential service of transferring grain between vessels in the harbor, thus avoiding costly delays and spoilage.

c. Airport Developments. The Port Authority operates the region's four major air terminals-New York International and La Guardia Airports in New York, and Newark and Teterboro Airports in New Jersey. It also operates two heliports, one located in midtown and the other, opened in December r 960 , in downtown Manhattan.

Two recent developments have occurred at New York International Airport which merit attention. First, the Port Authority's new passenger terminal development known as Terminal City was officially opened last year. At present the "City" consists of an International Arrival Building with two adjoining Airline Wing Buildings. When completed, the "City" will include several additional airline terminal buildings with connecting roadways, taxiway and aprons, all located within a 655 acre landscaped oval.

Second, October $195^{8}$ marked the commencement of regularly scheduled jet operations at the airport under controlled conditions designed to insure that the noise characteristics of the jet aircraft would prove to be tolerable to the residents of communities surrounding the airport. Jet flights have also necessitated costly runway extensions, as well as certain precautionary construction to protect persons on the airport itself.

At Newark Airport the Port Authority is in the process of constructing a new cargo handling center, as well as a new control tower. La Guardia Airport is also the scene of extensive redevelopment which includes a large new passenger terminal and an increase in aircraft gate positions by as much as fifty per cent.

d. Port Promotion and Protection. Three years ago the Port Authority had already undertaken a large scale program of port protection and promotion, including the establishment of regional trade promotion offices in New York City, Chicago, Cleveland, Washington, D.C., and in Rio de Janeiro, Brazil. Since then, the Port Authority has established three additional offices-in London, England, in Zurich, Switzerland, in San Juan, Puerto Rico, and in Pittsburgh.

The function of these offices is to attract new and increased freight routings to the Port of New York by performing a wide range of services to export-import shippers and others engaged in international trade. 
e. The Port Authority's Limited Entry Into the New York Commuter. Railroad Crisis. The recent developments previously described are well within the basic: legal and financial pattern of historic Port Authority operations. However, recently the Port Authority has entered an important new field which lies outside its traditional role-participation in New York State's newly adopted commuter rail transit program.

Ever since the end of World War II, commuter railroads in the New York-New Jersey metropolitan area, as well as elsewhere throughout the nation, have been faced. with mounting deficits caused by steadily diminishing passenger use and steadily rising operating costs. These conditions have already led to the abandonment of certain segments of rail service in the port area and threaten, if not alleviated by Government action, to result in the wholesale discontinuance of existing commuter rail service-service which is vitally needed for the region's continued economic well-being.

Over the years, many private and governmental agencies, including the Port Authority, have studied this perplexing problem. Certain individuals recognizingthe Port Authority's expertise in terminal and transportation matters, have called: upon it single-handedly to "take over" and "solve" the commuter railroad crisis. In response to these demands, the Port Authority has pointed out that rail transit is, and inevitably will continue to be, a deficit operation and that the assumption of. such deficits by the Port Authority is not only precluded by existing Port Authority statutory and contractual commitments, but would result in crippling and ultimately ruining the Port Authority's credit standing, thus bringing to a halt its bi-state: program for the continued development of essential port facilities, airports, and arterial highway connections. The fact is, as we have seen, that if the basic concept of the Port Authority is not to be destroyed, Port Authority facilities must ultimatelyr prove capable of self-support.

In devising his Administration's plan to meet the commuter crisis, both Governor Rockefeller and his Special Consultant on Transportation, Robert W. Purcell, recognized these limitations on the Port Authority's power-limitations inherent in the very nature of a self-supporting, non-partisan, public corporation-and together with the Port Authority worked out a feasible program which would: enable the Port Authority to use its administrative, financial, and legal skills in the transportation field to contribute, in part, to a solution of the commuter railroad: problem.

The plan Governor Rockefeller submitted to the Legislature emphasized the need to provide commuters with improved facilities, since much of the equipment used by commuter railroads has been in service for more than forty years. The: Governor pointed out that the railroads' financial plight makes it both costly andi difficult for them to borrow the needed funds with which to purchase new equipment. He noted that the commuter railroads would be greatly aided if they could! rent such equipment from the Port Authority and, hence, he recommended that the 
Port Authority be authorized to purchase passenger cars and locomotives and to lease them to commuter railroads at reasonable terms for a long period of years. Governor Rockefeller said: ${ }^{17}$

In order to avoid any possible impairment of the Port Authority's credit, I propose that the State advance $\$ 20,000,000$ from its capital construction fund to the Port Authority for the purchase of equipment. This sum would eventually be repaid from the rentals that the Port Authority would receive from the railroads or from the sale of bonds to the public.

I also recommend adoption of a constitutional amendment permitting the State to guarantee a maximum amount of $\$$ roo million of Port Authority bonds issued for the purpose of financing the purchase-lease program and for repaying the State's advances.

In addition to providing new railroad equipment, other phases of the Governor's comprehensive attack on the commuter rail crisis-phases which do not involve the Port Authority-include: (a) both interim and long-range railroad tax relief; (b) State aid to municipalities to offset losses in real estate tax revenues which might result from railroad tax relief; (c) administrative adjustment of the State's so-called "Full Crew" law, which prescribes the minimum personnel to be employed on trains operating within the State; and (d) the creation of a new bi-state agency with New Jersey for the handling of common commuter problems on both a short- and longterm basis.

The Legislature adopted those aspects of the Governor's program which required statutory sanction. ${ }^{18}$ In the legislation relating to commuter railroad equipment, the State of New York authorizes the Port Authority to spend $\$ 20,000,000$ from its general funds for the purpose of purchasing railroad cars and equipment to be leased to the commuter railroads. ${ }^{19}$

The legislation also empowers the Port Authority to borrow money for similar purposes upon the adoption of an amendment to the New York Constitution which would make the State liable for the repayment of the money so borrowed and the interest thereon. As the Governor's message indicates, the constitutional amendment, when adopted, will authorize Port Authority borrowing, for commuter railroad equipment purposes, to a maximum of \$100,000,000. Before the constitutional amendment can take effect, it has to be adopted by the new r96r Legislature ${ }^{20}$ and, thereafter, must be approved by the people. ${ }^{21}$ In the interim, the Port Authority will, of course, proceed with the purchase and lease of equipment on the basis of the State's $\$ 20,000,000$ appropriation.

\footnotetext{
${ }^{17}$ Governor's Message to the Legislature, March 20, 1959, Recommending a Program to Attack the Transportation Ills Which Beset the State, in State of New York, Public Papers of Nelson A. RockzFELIER, 53RD GOVERNOR OF THE STATE OF NEW YORK, 1959, at 130, 134 (1961).

${ }^{18}$ N.Y. Unconsol. Laws $\$ \$ 664 \mathrm{I}-6648$ (McKinney 1960 Supp.) (Port Authority authorization); N.Y. Sess. Laws 1959, chs. 639-64I (commuter railroad legislation not involving the Port Authority).

${ }^{19}$ N.Y. Unconsol. Laws $\$ \$ 66_{4} \mathrm{I}-66_{4} 8$ (McKinnicy 1960 Supp.).

${ }^{20}$ This legislation was adopted by the 196r Legislature as Laws of New York, 196x, ch. 312.

21 The proposed amendment was approved by the people in a referendum on Nov. $7,196 \mathrm{r}$. See New York Times, Nov. 9, $196 \mathrm{r}$, p. 24, col. 3 .
} 
The Purcell Report, upon which both the Governor's recommendations and the subsequently enacted legislation were based, pointed out that ${ }^{22}$

It should be possible to expand the equipment purchase program through monies derived from private banking sources based upon the pledge of the payment of railroad rentals or other payments on a normal equipment trust schedule and having the equity advantage, say to the extent of a $25 \%$ down payment on the equipment, provided by the State advances to the Port Authority. Repayment of the State's advances would be subordinated to such bank loans. By resort to such private sources, sufficient funds might be made available to meet the entire reasonable needs for new equipment of the three commuter railroads serving residents of New York.

The Purcell Report observed that its program

... would give to the people of the State the benefit of the experience and efficiency of the Port Authority and its broad background in all phases of transportation in the New York Metropolitan area....

The concurrently enacted New Jersey legislation, ${ }^{23}$ made necessary by the Port Authority's bi-state status, provided that the Port Authority powers relating to commuter railroad equipment are not to be effective until Congress approves a Compact creating a new bi-state transportation agency. The House of Representatives has already approved this Compact, and it is expected that the Senate will do likewise.

The Port Authority, however, has not been marking time. Immediately after the legislation's adoption it commenced a series of meetings with railroad representatives to determine their equipment needs. In addition, it has been working out the necessary financing details. I want to emphasize that the railroad equipment program does not involve the use of Port Authority revenues or reserves in any manner or form, directly or indirectly.

In concluding, I should like to underscore one point: although the Port Authority is subject to democratic controls, its activities have always been conducted without reference to partisan political considerations. If this were otherwise, it could not long endure as a useful interstate mechanism. The absence of partisan politics in Port Authority endeavors is seen from the following statements rendered a few years ago by two well-known political opponents, both former Governors of New York. Republican Governor Dewey said: ${ }^{24}$

Through its great public works, [the Port Authority] has set an example for the administration of public business on a sound and efficient basis. Its prudent management has. established a credit rating unique among government agencies. ... I am proud to say that [the Port Authority Commissioners] set an example of high integrity in government officials.

\footnotetext{
${ }^{22}$ Robert W. Purceld, Spectal Report to the Governor on Problems of the Railroad and Bus LINES IN NEW YORR STATE 31, 35 (I959).

${ }_{25}$ N.J. STAT. ANN. $\$ \$$ 32:2-23.20 to 32:2-23.26 (I960 Supp).

${ }^{24}$ Letter in opposition to H.J. Res. 375, in Hearing Held Before Subcommittee No. 5 of the House Comm. on the Judiciary on H.J. Res. 375, To Rescind the Consent of Congress Creating The Port of New York Authority, May 21, 1952 (Stenographic Report, pp. 25I, 252, 253).
} 
Democratic Governor Lehman observed that Port Authority facilities demonstrate that a public agency can plan and execute activities ${ }^{25}$

-.. with an ability which measures up to our highest standard of industrial efficiency and with a selfless devotion to the public good which reflects our highest ideal of Government.

On the other side of the Hudson, a similar high opinion of the Port Authority and its activities is expressed by New Jersey political leaders. While still in office, former Governor Driscoll cited with approval the Port Authority's "works, its credit standing, its reputation and its responsiveness to our regional problems in the continued development of our joint Port area," and further stated:28

I speak for the people of New Jersey when I say that we are proud of the work that we have accomplished through this bi-state agency, which serves the citizens of our two states well; and I think have made a great contribution not only to the economy of our area but the well-being of our entire country.

\section{More recently, Governor Meyner said:27}

Each succeeding accomplishment of The Port of New York Authority re-emphasizes the amazing foresight of those who, by fostering the bi-state Compact of 1921, were responsible for the establishment of this great public agency. As a result of the unselfish public zeal and statesmanship of a few men, led by Governor Walter E. Edge of New Jersey and Governor Alfred E. Smith of New York, destructive competition between the States was replaced by beneficial cooperation.

${ }^{20}$ Letter in opposition to H.J. Res. 375 , id. at $243,246$.

${ }^{20}$ Statement of Governor Driscoll, id. at 274, 278.

${ }^{27}$ Speech delivered at the dedication ceremonies of the Lincoln Tunnel, Third Tube, on May 25, 1957. 